\title{
Front Matter: Volume 9109
}

, "Front Matter: Volume 9109," Proc. SPIE 9109, Compressive Sensing III, 910901 (11 June 2014); doi: 10.1117/12.2072203

SPIE Event: SPIE Sensing Technology + Applications, 2014, Baltimore, MD, United SPIE. States 


\section{PROCEEDINGS OF SPIE}

\section{Compressive Sensing III}

Fauzia Ahmad

Editor

7-9 May 2014

Baltimore, Maryland, United States

Sponsored and Published by

SPIE 
The papers included in this volume were part of the technical conference cited on the cover and title page. Papers were selected and subject to review by the editors and conference program committee. Some conference presentations may not be available for publication. The papers published in these proceedings reflect the work and thoughts of the authors and are published herein as submitted. The publisher is not responsible for the validity of the information or for any outcomes resulting from reliance thereon.

Please use the following format to cite material from this book:

Author(s), "Title of Paper," in Compressive Sensing III, edited by Fauzia Ahmad, Proceedings of SPIE Vol. 9109 (SPIE, Bellingham, WA, 2014) Article CID Number.

ISSN: 0277-786X

ISBN: 9781628410464

Published by

SPIE

P.O. Box 10, Bellingham, Washington 98227-0010 USA

Telephone +1 3606763290 (Pacific Time) · Fax +1 3606471445

SPIE.org

Copyright (C) 2014, Society of Photo-Optical Instrumentation Engineers.

Copying of material in this book for internal or personal use, or for the internal or personal use of specific clients, beyond the fair use provisions granted by the U.S. Copyright Law is authorized by SPIE subject to payment of copying fees. The Transactional Reporting Service base fee for this volume is $\$ 18.00$ per article (or portion thereof), which should be paid directly to the Copyright Clearance Center (CCC), 222 Rosewood Drive, Danvers, MA 01923. Payment may also be made electronically through CCC Online at copyright.com. Other copying for republication, resale, advertising or promotion, or any form of systematic or multiple reproduction of any material in this book is prohibited except with permission in writing from the publisher. The CCC fee code is 0277-786X/14/\$18.00.

Printed in the United States of America.

Publication of record for individual papers is online in the SPIE Digital Library.

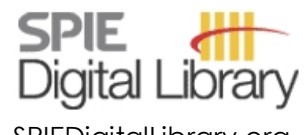

SPIEDigitalLibrary.org

Paper Numbering: Proceedings of SPIE follow an e-First publication model, with papers published first online and then in print and on CD-ROM. Papers are published as they are submitted and meet publication criteria. A unique, consistent, permanent citation identifier (CID) number is assigned to each article at the time of the first publication. Utilization of CIDs allows articles to be fully citable as soon as they are published online, and connects the same identifier to all online, print, and electronic versions of the publication. SPIE uses a six-digit CID article numbering system in which:

- The first four digits correspond to the SPIE volume number.

- The last two digits indicate publication order within the volume using a Base 36 numbering

system employing both numerals and letters. These two-number sets start with 00, 01, 02, 03, 04,

$05,06,07,08,09,0 A, 0 B \ldots$. OZ, followed by 10-1Z, 20-2Z, etc.

The CID Number appears on each page of the manuscript. The complete citation is used on the first page, and an abbreviated version on subsequent pages. Numbers in the index correspond to the last two digits of the six-digit CID Number. 


\section{Contents}

vii Conference Committee

COMPRESSIVE SENSING FOR RADAR II: JOINT SESSION WITH 9077 AND 9109

$910902 \quad$ Multi-static passive SAR imaging based on Bayesian compressive sensing [9109-1]

Q. WU, Y. D. Zhang, M. G. Amin, Villanova Univ. (United States); B. Himed, Air Force Research Lab. (United States)

$910903 \quad$ Multi-target compressive laser ranging [9109-2]

P. P. Pandit, J. R. Dahl, Z. W. Barber, W. R. Babbitt, Montana State Univ. (United States)

910904 Sparsity-based ranging for dual-frequency radars [9109-3]

F. Ahmad, K. Al Kadry, M. G. Amin, Villanova Univ. (United States)

910905 Analysis of the tolerance of compressive noise radar systems to multiplicative perturbations [9109-4]

M. C. Shastry, 3M Co. (United States); R. M. Narayanan, The Pennsylvania State Univ. (United States); M. Rangaswamy, Air Force Research Lab. (United States)

910906 CS-MIMO radars for through-the-wall imaging in an indoor multipath environment [9109-5] Y. Yu, Rutgers, The State Univ. of New Jersey (United States); F. Ahmad, Villanova Univ. (United States); A. P. Petropulu, Rutgers, The State Univ. of New Jersey (United States); M. G. Amin, Villanova Univ. (United States)

\section{COMPRESSIVE SENSING SIGNAL PROCESSING}

910907 Asynchronous signal-dependent non-uniform sampler [9109-6]

A. Can-Cimino, L. F. Chaparro, E. Sejdić, Univ. of Pittsburgh (United States)

910908 Sparse reconstruction of multi-window time-frequency representation based on Hermite functions [9109-7]

B. Jokanović, M. G. Amin, Y. D. Zhang, Villanova Univ. (United States)

9109 OA Compressive sensing of direct sequence spread spectrum signals [9109-9]

F. Liu, M. W. Marcellin, The Univ. of Arizona (United States); N. A. Goodman, The Univ. of Oklahoma (United States); A. Bilgin, The Univ. of Arizona (United States)

9109 OB Reducing noise in the time-frequency representation using sparsity promoting kernel design [9109-10]

B. Jokanović, M. G. Amin, Y. D. Zhang, Villanova Univ. (United States)

9109 OC Using computer algebra to perform image compression with wavelet transform and SVD [9109-11]

F. Díaz, Univ. EAFIT Univ. (Colombia) 
9109 OD Compressive spectral polarization imaging [9109-12]

C. Fu, H. Arguello, G. R. Arce, Univ. of Delware (United States); V. O. Lorenz, Univ. Industrial de Santander (Columbia)

9109 OE Digital speckle reduction in holograms: a comparison between methods [9109-14] A. Stern, V. Farber, A. Uzan, Y. Rivenson, Ben-Gurion Univ. of the Negev (Israel)

9109 OF Experimental study of super-resolution using a compressive sensing architecture [9109-15] J. C. Flake, The MITRE Corp. (United States) and Booz Allen Hamilton Inc. (United States); G. Euliss, The MITRE Corp. (United States); J. B. Greer, S. Shubert, National GeospatialIntelligence Agency (United States); G. Easley, K. Gemp, The MITRE Corp. (United States); B. Baptista, National Geospatial-Intelligence Agency (United States); M. D. Stenner, The MITRE Corp. (United States); P. A. Sallee, Booz Allen Hamilton Inc. (United States)

\section{SPARSE RECOVERY ALGORITHMS AND IMPLEMENTATIONS}

9109 OG Parallel heterogeneous architectures for efficient OMP compressive sensing reconstruction [9109-17]

A. Kulkarni, J. L. V. M. Stanislaus, T. Mohsenin, Univ. of Maryland, Baltimore County (United States)

9109 0J Direction finding with L1-norm subspaces [9109-20]

P. P. Markopoulos, N. Tsagkarakis, D. A. Pados, Univ. at Buffalo (United States);

G. N. Karystinos, Technical Univ. of Crete (Greece)

COMPRESSIVE SENSING FOR MEDICAL, ACOUSTICAL, AND ULTRASOUND APPLICATIONS

$9109 \mathrm{OL}$ Compressive sensing optical coherence tomography using randomly accessible lasers [9109-22]

M. Harfouche, California Institute of Technology (United States); N. Satyan, Telaris, Inc. (United States) and California Institute of Technology (United States); A. Vasilyev, A. Yariv, California Institute of Technology (United States)

$91090 \mathrm{M}$ Understanding differences between healthy swallows and penetration-aspiration swallows via compressive sensing of tri-axial swallowing accelerometry signals [9109-23] E. Sejdić, J. M. Dudik, A. Kurosu, I. Jestrović, J. L. Coyle, Univ. of Pittsburgh (United States)

9109 ON Highly accelerated 3D dynamic contrast enhanced MRI from sparse spiral sampling using integrated partial separability model and JSENSE [9109-24] J. Lyu, Univ. at Buffalo (United States); P. Spincemaille, Y. Wang, Weill Cornell Medical College (United States); Y. Zhou, F. Ren, L. Ying, Univ. at Buffalo (United States)

910900 Graphics processing units accelerated MIMO tomographic image reconstruction using target sparseness [9109-25]

P. D. Bello-Maldonado, Florida International Univ. (United States); A. Rivera-Longoria, Texas State Univ. (United States); M. Idleman, Ahmerst College (United States); Y. Jin, Univ. of Maryland Eastern Shore (United States); E. Lu, Salisbury Univ. (United States) 
9109 OP Multimodal sparse reconstruction in Lamb wave-based structural health monitoring [9109-26]

A. Golato, S. Santhanam, F. Ahmad, M. G. Amin, Villanova Univ. (United States)

COMPRESSIVE SENSING FOR SPECTRAL IMAGING, OPTICAL IMAGING, AND VIDEO II

$91090 Q \quad$ Lensless coded aperture imaging with separable doubly Toeplitz masks [9109-27]

M. J. DeWeert, B. P. Farm, BAE Systems Spectral Solutions (United States)

9109 OR Rate-distortion optimization for compressive video sampling [9109-28]

Y. Liu, K. R. Vijayanagar, J. Kim, Illinois Institute of Technology (United States)

9109 OS Image estimation from projective measurements using low dimensional manifolds [9109-29]

J. Veras, Lockheed Martin Corp. (United States) and Univ. of Central Florida (United States);

R. Muise, Lockheed Martin Corp. (United States)

9109 OT A fast target detection and imaging method for compressive sensing Earth observation [9109-30]

C. Li, Academy of Opto-Electronics (China); Q. Wang, Academy of Opto-Electronics (China) and Univ. of Chinese Academy of Sciences (China); C. Cao, NOAA-NESDIS Ctr. for Satellite Application and Research (United States); X. Shao, Univ. of Maryland, College Park (United States); L. Ma, Y. Zhou, Academy of Opto-Electronics (China); S. Qiu, Univ. of Maryland, College Park (United States); J. Li, Academy of Opto-Electronics (China), Univ. of Chinese Academy of Sciences (China), and NOAA-NESDIS Ctr. for Satellite Application and Research (United States)

9109 OU A new approach to apply compressive sensing to LIDAR sensing [9109-31]

R. C. Lau, T. K. Woodward, Applied Communication Sciences (United States)

9109 OV 3D imaging using compressive line sensing serial imaging system [9109-13]

B. Ouyang, F. M. Caimi, F. R. Dalgleish, Harbor Branch Oceanographic Institute at Florida Atlantic Univ. (United States); G. Nootz, Naval Post Graduate School (United States); A. K. Vuorenkoski, Harbor Branch Oceanographic Institute at Florida Atlantic Univ. (United States)

Author Index 
Proc. of SPIE Vol. $9109910901-6$

Downloaded From: https://www.spiedigitallibrary.org/conference-proceedings-of-spie on 26 Apr 2023 Terms of Use: https://www.spiedigitallibrary.org/terms-of-use 


\section{Conference Committee}

Symposium Chair

David A. Whelan, Boeing Defense, Space, and Security

(United States)

Symposium Co-chair

Wolfgang Schade, Technische Universität Clausthal (Germany) and

Fraunhofer Heinrich-Hertz-Institut (Germany)

Conference Chair

Fauzia Ahmad, Villanova University (United States)

Conference Program Committee

Gonzalo R. Arce, University of Delaware (United States)

Moeness G. Amin, Villanova University (United States)

Abdesselam Salim Bouzerdoum, University of Wollongong (Australia)

Matthew A. Herman, InView Technology Corporation (United States)

Rabinder N. Madan, Office of Naval Research (United States)

Eric L. Mokole, U.S. Naval Research Laboratory (United States)

Ram M. Narayanan, The Pennsylvania State University (United States)

Dimitris A. Pados, University at Buffalo (United States)

Athina P. Petropulu, Rutgers, The State University of New Jersey

(United States)

Lei (Leslie) Ying, University at Buffalo (United States)

\section{Session Chairs}

1 Compressive Sensing for Radar I: Joint Session with 9077 and 9109

Lam H. Nguyen, U.S. Army Research Laboratory (United States)

2 Compressive Sensing for Radar II: Joint Session with 9077 and 9109

Eric L. Mokole, U.S. Naval Research Laboratory (United States)

3 Compressive Sensing Signal Processing

Emre Ertin, The Ohio State University (United States)

4 Compressive Sensing for Spectral Imaging, Optical Imaging, and Video I

Michael J. DeWeert, BAE Systems (United States) 
5 Sparse Recovery Algorithms and Implementations

Adrian Stern, Ben-Gurion University of the Negev (Israel)

6 Compressive Sensing for Medical, Acoustical, and Ultrasound Applications

Ervin Sejdić, University of Pittsburgh (United States)

7 Compressive Sensing for Spectral Imaging, Optical Imaging, and Video II

Ervin Sejdić, University of Pittsburgh (United States) 